\title{
Smiling in the Face of Adversity: A Spouse's Account of Recovery and Personal Growth
}

As the mother of two children, I occupied myself as a homemaker, and enjoyed a peaceful life until my husband's business closed down in 2003. From then on, he started asking for money, giving me various reasons. I gave him half a million to run a poultry business, but weeks later he wanted another million to set up a car washing business. I trusted him as usual until he returned home one day with debt collectors. I was shocked and forced to sell my apartment to repay his debts. Sadly, this crisis coincided with my son's wedding, and I found that I was unable to feel any happiness on this special occasion.

My children and I were fairly sure that my husband had become addicted to gambling but he denied this. Having no real understanding of problem gambling, we thought that helping him meant settling his gambling debts. We handed out four million dollars to him in the hope of solving his gambling problem which had become a source of family distress. I had never expected that on a cold rainy day we would have to flee our home to escape from loan sharks! I moved temporarily to a relative's house and literally collapsed. I was so thin, with my weight dropping to $79 \mathrm{lbs}$. I felt helpless and even thought of suicide. I was diagnosed as being severely depressed.

I repeatedly asked why this had happened to me? I just kept myself indoors, thinking or loitering around aimlessly. I felt that I had lost my soul. One day I realized that I could not stay like this forever. I had to change for the sake of those I cared about. I started searching for a way out. Beginning in 2006, I completed classes on self-help strategies, gardening, health and mood regulation. I became an active volunteer at a community center. Meanwhile, the debt collectors' harassment and my husband's requests for money continued. I began rejecting his requests firmly and to seek protection for my assets. I successfully differentiated my husband's financial responsibilities from my own. As a result, I kept my property and savings and tried to start a new life.

In 2004, my husband and I sought help from Caritas Addicted Gamblers Counselling Centre but soon he dropped out when his endless demands for money were continually turned down. I insisted on joining activities at the Centre (e.g. family and mutual support groups). I told myself, I should not 'run away' from difficulties as he was doing. I received training as a peer supporter at the Centre, and have been helping other family members of problem gamblers for some years now. I also became involved as an advocate for care and services for gamblers' families. For example, I shared my personal experiences with Legislative Councilors as 
part of an empowerment initiative.

Now I am contented in myself and much healthier. About six months ago, my doctor told me that I had recovered from my severe depression and no longer needed any medication. I was so happy and could hardly wait to share this good news to my friends at the Centre. They had witnessed my struggles and also my 'bouncing back'!

If you are distressed because of the gambling problems of family members or significant others, take the first step and seek help! Change is possible.

Edited by Patrick Tak Ching Lau Counselor of Caritas Addicted Gamblers Counselling Centre Hong Kong 